\title{
Deviasi Orientasi Gerakan Dakwah Partai Keadilan Sejahtera
}

\author{
Wiryo Setiana \\ UIN Sunan Gunung Djati Bandung \\ E-mail:wiryo_setiana@yahoo.co.id
}

\begin{abstract}
The strategy of PKS as a da'wah party in the transformation of the nation, is a cultural movement and structural movement. Horizontal mobilization to spread of cadres in various groups and segments of society to prepare the community so they receive manhaj Islam and Islamic policy products. In general, the basic policy principles adopted by PKS reflected fully in their identity as Da'wah Party. While proselytizing is believed PKS is proselytizing rabbaniyah rahmatan lil'alamin, that proselytizing is guiding people to know God and proselytizing is addressed to all mankind that bring solutions to the problems it faces. He is da'wah fair towards brotherhood among mankind, far from forms of racism or bigotry ethnicity, race, or ethnicity.
\end{abstract}

\section{Kata kunci:}

Deviasi, Gerakan dakwah, Dakwah Politik

\section{A. Pendahuluan}

Pemilihan Umum merupakan momentum terpenting sebuah bangsa. Ia merupakan salah satu tahapan dalam proses pemilihan pemimpin yang kelak akan melanjutkan penyelenggaraan sebuah proses pemerintahan. Tidak terkecuali di negara kita, Pemilu menjadi harapan terakhir bagi seluruh komponen bangsa untuk memperbaiki negeri ini. Oleh karenanya mereka melihat hal ini sebagai sebuah pesta demokrasi, sebuah pesta rakyat.

Dalam konteks keindonesiaan, Heru Nugroho (2008), salah seorang Guru Besar Universitas Gadjahmada mengungkapkan bahwa demokratisasi yang bergulir sejak reformasi dan sudah berlangsung satu dekade lebih harus diakui telah menghasilkan kemajuan di 
berbagai bidang. Capaian monumental adalah terselenggaranya pemilu legislatif langsung tahun 1999 yang kemudian menjadi titik awal era multipartai.

Pada tahun 2004 terselenggara pemilihan langsung presiden dan wakil presiden dan sejak 2005 hingga sekarang telah terselenggara ratusan kali pilkada gubernur, wali kota, dan bupati. Demokrasi prosedural dalam bentuk penyelenggaraan pemilu langsung telah menempatkan Indonesia sebagai negara demokrasi terbesar ketiga setelah AS dan India.

Situasi seperti ini juga mendorong meningkatnya partisipasi warga dalam politik, terbangunnya regulasi tata kelembagaan, independensi penyelenggaraan pemilu, penjaminan hak sipil dan politik, penguatan isu-isu perempuan, terwujudnya kebebasan pers, otonomi daerah dan desentralisasi, dan lain-lain.

Ironisnya, demokrasi prosedural yang sedang berlangsung kadang tidak disertai terbentuknya demokrasi substansial. Demokrasi yang sedang berproses ada di bawah bayang-bayang terwujudnya demokrasi beku (frozen democracy), yaitu suatu fase yang ditandai kemandekan. Buktinya, pemilu langsung yang telah terselenggara dengan biaya cukup besar dari jenjang pilpres hingga pilkada tidak otomatis menghasilkan berbagai kebijakan publik yang memihak rakyat kecil. Demokrasi yang digunakan sebagai instrumen untuk mencapai tujuan seperti kebebasan, keadilan, dan kesejahteraan sosial masih sekadar menjadi cita-cita kita semua.

Politik uang masih merebak di segala tingkat pemilu. Akibatnya, mereka yang dapat maju sebagai calon pemimpin hanya terbatas dari kalangan yang memiliki dana besar, bukan karena kapasitas dan kapabilitas sebagai calon pemimpin. Banyak contoh bisa disebut, misalnya seorang mantan preman yang telanjur kaya dapat terpilih menjadi pemimpin, bekas penjarah hutan terpilih menjadi wali kota, bekas cukong bisnis gelap terpilih menjadi anggota legislatif, dan sebagainya.

Selain itu, oligarki partai yang dipicu kepentingan para elite menghasilkan para calon pemimpin yang bukan pilihan rakyat, tetapi yang punya uang dan memiliki relasi kolusif dengan elite-elite partai. Wajar jika para pemimpin yang telah terpilih tidak merepresentasikan 
kepentingan rakyat, tetapi cenderung melakukan politik representasi atas kepentingan rakyat dalam rangka mengembalikan modal ekonomi yang telah diinvestasikan selama masa pemilu.

Pada pilpres 2009 terdapat beberapa pelanggaran yang tidak diproses oleh Bawaslu, tidak kurang dari 1.018 pelanggaran pilpres yang dilakukan oleh partai-partai besar pengusung capres dan cawapres dalam kampanye baik sebelum maupun sesusah kampanye. Kenapa Badan Pengawas Pemilu tidak memproses secara hukum pada pelanggaran pidana pemilu (HU Sinar Harapan, 2009).

Kondisi ini pula yang melahirkan fenomena pluralisme semu. Jargon "Bhinneka Tunggal Ika" yang mengakui kemajemukan tetap dibayang-bayangi paradigma nation state yang mengintrodusir politik monokultur satu nusa, satu bangsa, dan satu bahasa. Namun, saat etika semangat multikultur terus bergulir, pemerintahan SBY dihadapkan soal besar yang belum selesai, yaitu diskriminasi dan tindak kekerasan terhadap Ahmadiyah. Sungguh merupakan ironi politik multikultur karena pada satu sisi memberi kebebasan melakukan ritual keagamaan terhadap etnis China, tetapi gagal memberi perlindungan kebebasan mengekspresikan kepercayaan bagi penganut Ahmadiyah. Apa pun argumen di balik pelarangan praktik Ahmadiyah, aspek keadilan cenderung diabaikan dalam politik multikultur kita.

Bisa jadi, kita kini sedang terjebak fenomena pseudo multiculturalism yang ditandai dengan sekadar mengekspresikan keyakinan, meritualkan tradisi, dan merayakan perbedaan, tetapi sebetulnya kita sedang menjauh dari esensi multikulturisme yang seharusnya berbasis keadilan. Dalam politik multikultur, keadilan merupakan prasyarat mutlak dengan tiga aspek rekognisi, redistribusi (penguasaan sumber-sumber ekonomi), dan representasi sebagai pilarpilar penopangnya. Maka tidak mengherankan jika ritual Imlek di klenteng-klenteng yang ditandai dengan membagi-bagi angpau oleh etnis China kepada pribumi justru merupakan legitimasi peneguhan posisi kelas dominan. Fenomena ini merepresentasikan minoritas etnis yang menguasai mayoritas sumber daya ekonomi. Politik kemajemukan budaya tanpa mempertimbangkan aspek pengakuan, redistribusi, dan representasi yang hakiki sama artinya dengan mengingkari keadilan dan cenderung terjebak perangkap kemajemukan semu. 
Selain itu, penegakan hukum pasca-reformasi merupakan faktor penting dalam menjaga arah demokrasi. Tanpa tegaknya sistem hukum di Tanah Air, demokratisasi hanya akan melahirkan deviasi-deviasi baru seperti anarkisme, kekerasan, dan ketidakpastian hukum dan keadilan yang dirasakan oleh rakyat yang ujung-ujungnya rakyat menjadi korban para elit politik yang hanya mementingkan kelompok dan dirinya sendiri.

Perlu diakui, demokratisasi telah membuat warga dapat mengekspresikan dan mengartikulasikan kehendaknya, tetapi kadang artikulasi kepentingan oleh massa sering tidak terkontrol sehingga sering mengarah pada tindakan anarkisme massa yang melawan hukum. Misalnya, berbagai tuntutan buruh, resistensi masyarakat terhadap berbagai proyek pemerintah, dan tuntutan mahasiswa sering kali tidak mengindahkan rule of the game dan rule of law sehingga memunculkan tindakan kekerasan sipil atau brutalisme massa.

Selain itu, maraknya tindak penyalahgunaan kekuasaan oleh jajaran eksekutif, legislatif, dan yudikatif (mafia peradilan) merupakan indikator belum adanya penghayatan dan toleransi terhadap penderitaan rakyat sehingga mengancam proses demokrasi. Pada perspektif patologi sosial terjadilqah deviasi atau penyimpangan dimana-mana, sehingga mengakibatkan devias situasional yang kumulatif (Kartono, 2005) dikalangan para penyelenggara negara.

Meski pemerintahan SBY telah berupaya mengatasi masalah ini, hasilnya belum maksimal. Berbagai produk perundang-undangan sebenarnya sudah banyak yang dilandasi spirit demokrasi, tetapi pelaksanaannya jauh dari gambaran normatif, bahkan tidak jarang justru yang terjadi sebaliknya, membuat undang-undang untuk tidak ditaati, atau ramai-ramai dilanggar. Kondisi seperti ini menghasilkan efek imitasi sehingga melahirkan gejala "spiral pelanggaran hukum" yang tak berujung pangkal.

\section{B. PKS Sebagai Partai Dakwah}

Setelah matang dalam wacana dan ranah ajaran Islam yang syamil, haffah, dan tawazun, muncullah pergulatan antara perlunya gerakan tarbiyah memasuki pentas politik atau tetap konsisten di jalur dakwah. Dakwah menurut konseptor sekaligus negarawan dunia Ibnu Khaldun 
akan menambah kuat solidaritas sisoal bagi para pelaku maupun objek dakwah. Akumulasi gerakan dakwah yang professional dan maksimum, sebagaimana diterapkan Rasulullah, menghasilkan out put yang baik (Khaldun, t.th.: 192-193).

Pergulatan antara dakwah dan politik ini sempat mewarnai pada masa-masa awal gerakan tarbiyah di Indonesia ketika hendak membentuk partai Keadilan (PK). Pergulatan tersebut juga pernah dialami oleh Ikhwanul Muslimin, namun demikian akhirnya kebulatan tekad untuk menegakan Islam melalui penas politik pun diikrarkan.

Perlunya mendeklarasikan partai islam oleh PK lantaran didasari kekesewaan terhadap partai Silam yang telah ada, yangs ecara diametral sebenarnya dianggap gagal memperjuangkan nasib rakyat yang meyoritas muslim. Bahkan yang lebih esensial, partai islam yang ada dinilai kurang memegang teguh ajaran Islam sebagai ruh gerakan politiknya, yang muncul hanyalah langkah-langkah pragmatis yang secara perlahan namun pasti menyingkirnkan nilai-nilai Islam itu sendiri dari partai Islam yang ada (Edward, 2006).

Menyahuti tuntutan reformasi pada tahun 1998, Partai Keadilan Sejahtera yang pada waktu itu masih bernama Partai Keadilan dideklarasikan pada tanggal 9 Agustus 1998 di lapangan Masjid Al Azhar, Kebayoran Baru, Jakarta Selatan dihadiri oleh 50.000 massa, partai dakwah berasas Islam ini menorehkan kehadirannya di bumi Indonesia. Dalam waktu singkat partai ini berusaha mengkonsolidasikan diri dan ikut bersaing meraih simpati rakyat dengan lebih dari setarus partai politik lainnya, termasuk 3 partai politik yang muncul pada masa orde baru.

Dari waktu ke waktu, Partai Keadilan dianggap mampu menciptakan partainya sebagai mesin politik yang berbasis pada kadernya. Pada Pemilu 2004, Partai Keadilan mengubah dirinya menjadi Partai Keadilan Sejahtera (PKS). Partai Keadilan Sejahtera merupakan pelanjut perjuangan Partai Keadilan (PK) yang dalam pemilu 1999 meraih 1,4 juta suara (7 kursi DPR, 26 kursi DPRD Propinsi dan 153 kursi DPRD Kota/Kabupaten).

Pada pemilu 2004, dengan kampanye-kampanye yang meriah, kreatif, tertib dan santun, PKS yang mendapat nomor urut 16 ini mengusung jargon bersih dan peduli, sebuah karakteristik yang harus 
diwujudkan dalam dakwah Islam. Kerja keras dan pengorbanan seluruh kader PKS untuk memenangkan pemilu membuahkan hasil yang fantantis dan fenomental. Dukungan rakyat kepada partai ini melejit hampir 700 persen, dengan perolehan suara sebanyak 8,3 juta $(7,4$ persen), dan menempati rangkin ke-6. Konsekuensinya, sebanyak 45 kursi DPR RI,157 kursi DPRD Propinsi dan 900 kursi Kota/Kabupaten (Wahono, 2007: 20).

Dalam pemilihan presiden putaran pertama tahun 2004, PKS merekomendasikan calon presiden Prof. Dr. HM. Amien Rais kepada kader-kadernya walaupun dengan dukungan yang malu-malu kucing atau terlambat. Dalam pemlihan presiden putaran kedua, PKS melakukan koalisi dengan Susilo Bambang Yudoyono yang diusung pleh partai Demokrat, sedangkan kubu Megawati Soekarnoputri disukung oleh PDI Perjuangan, sebagian Partai Golkar, dan sebagian Partai Persatuan Pembangunan. Partai Amanat Nasional dan Kebangkitan Bangsa menyatakan netral dalam putaran kedua. Pasangan SBY-Jusuf Kalla berhasil menang telak dalam pemilihan tersebut dengan dukungan lebih dari $60 \%$. Konsekuensi dari koalisi tersebut, PKS diberi jatah oleh presiden terpilih sebanyak 3 menteri (Menteri Pertanian-Anton Apriantono, Menteri Perumahan- Yusuf As'ari, serta Menteri Pemuda dan Olah Raga- Adyaksa Dault).

Duduknya M Hidayat Nurwahid di kursi Ketua MPR, seperti biasa menjadi momentum keteladanan politik bagi bangsa ini. Santri jebolan Pesantren Gontor dan doctor lulusan Universitas Madinah ini mundur dari jabatannyasebagai Presiden PKS. Posisinya digantikan sementara oleh Tifatul Sembiring. Konsekuensinya, PKS menggelar Munas Pertamanya pada akhir Juli 2005 di Hotel Century di kawasan Senayan, Jakarta. Dalam musyawarah ini Tifatul Sembiring dikukuhkan sebagai Presiden PKS.

Dalam kurun waktu sepuluh tahun, PKS mampu menguatkan identitasnya sebagai Partai Dakwah. Hal ini dapat dilihat dari Anggaran Dasar dan Anggaran Rumah Tangga yang dimilikinya. Dalam Dasar Pemikiran yang tercantu dalam Kebijakan Dasar PKS diungkapkan sebagai berikut:

"Islam adalah sistem integral yang mampu membimbing ummat manusia menuju kesejahteraan lahir dan batin, duniawi dan 
ukhrawi. Kesejahteraan tersebut hanya dapat diwujudkan melalui dua kemenangan, yaitu kemenangan pribadi (futuh khashah) dan kemenangan politik (futuh ammah). Kemenangan pribadi diraih dengan ketaqwaan yang bersifat individu, sedangkan kemenangan politik diraih dengan ketaqwaan kolektif. Da'wah yang sistemik dan terus-menerus adalah satu-satunya jalan menuju dua kemenangan tersebut..."

Dilihat dari alinea pertama dasar pemikiran AD-ART PKS di atas, secara eksplisit mereka menyatakan diri sebagai partai dakwah dan secara terminologis dapat dipahami sebagai sebuah partai yang mengusung nilai-nilai dakwah Islam dalam seluruh aktivitas politiknya. Dengan kata lain mereka menekankan pada dakwah struktural.

Hal ini juga dapat dilihat dari visi yang dimiliki oleh PKS. Dalam visi umum, PKS menulis, "sebagai partai da'wah penegak keadilan dan kesejahteraan dalam bingkai persatuan ummat dan bangsa." Sementara pada visi khusus, PKS mengungkapkan, "partai berpengaruh baik secara kekuatan politik, partisipasi, maupun opini dalam mewujudkan masyarakat indonesia yang madani."

Visi ini kemudian mengarahkan Partai Keadilan Sejahtera sebagai:

1. Partai da'wah yang memperjuangkan Islam sebagai solusi dalam kehidupan berbangsa dan bernegara.

2. Kekuatan transformatif dari nilai dan ajaran Islam di dalam proses pembangunan kembali umat dan bangsa di berbagai bidang.

3. Kekuatan yang mempelopori dan menggalang kerjasama dengan berbagai kekuatan yang secita-cita dalam menegakkan nilai dan sistem Islam yang rahmatan lil 'alamin.

4. Akselerator bagi perwujudan masyarakat madani di Indonesia.

Visi ini kemudian diturunkan kedalam misi gerakan politik PKS sebagai berikut:

1. Menyebarluaskan da'wah Islam dan mencetak kader-kadernya sebagai anashir taghyir.

2. Mengembangkan institusi-institusi kemasyarakatan yang Islami di berbagai bidang sebagai markaz taghyir dan pusat solusi. 
3. Membangun opini umum yang Islami dan iklim yang mendukung bagi penerapan ajaran Islam yang solutif dan membawa rahmat.

4. Membangun kesadaran politik masyarakat, melakukan pembelaan, pelayanan dan pemberdayaan hak-hak kewarganegaraannya.

5. Menegakkan amar ma'ruf nahi munkar terhadap kekuasaan secara konsisten dan kontinyu dalam bingkai hukum dan etika Islam.

6. Secara aktif melakukan komunikasi, silaturahim, kerjasama dan ishlah dengan berbagai unsur atau kalangan umat Islam untuk terwujudnya ukhuwah Islamiyah dan wihdatul-ummah, dan dengan berbagai komponen bangsa lainnya untuk memperkokoh kebersamaan dalam merealisir agenda reformasi.

7. Ikut memberikan kontribusi positif dalam menegakkan keadilan dan menolak kedhaliman khususnya terhadap negerinegeri muslim yang tertindas.

Strategi PKS sebagai partai dakwah (khuthuth 'aridhah) dalam transformasi bangsa, adalah gerakan kultural (strategi mobilisasi horizontal/tabi'ah al afaqiyah) dan gerakan struktural (strategi mobilitas vertikal/tabi'ah al amudiyah). Mobilisasi horizontal merupakan penyebaran kader dakwah ke berbagai kalangan dan lapisan masyarakat untuk menyiapkan masyarakat agar mereka menerima manhaj Islam serta produk kebijakan yang Islami.

Secara umum prinsip kebijakan dasar yang diambil oleh Partai Keadilan Sejahtera terefleksi utuh dalam jati dirinya sebagai Partai Da'wah. Sedangkan da'wah yang diyakini Partai Keadilan Sejahtera adalah da'wah rabbaniyah yang rahmatan lil'alamin, yaitu da'wah yang membimbing manusia mengenal Tuhannya dan da'wah yang ditujukan kepada seluruh ummat manusia yang membawa solusi bagi permasalahan yang dihadapinya. Ia adalah da'wah yang menuju persaudaraan yang adil di kalangan ummat manusia, jauh dari bentukbentuk rasialisme atau fanatisme kesukuan, ras, atau etnisitas.

Atas dasar itu maka da'wah menjadi poros utama seluruh gerak partai. Ia juga sekaligus menjadi karakteristik perilaku para aktivisnya 
dalam berpolitik. Maka prinsip-prinsip yang mencerminkan watak da'wah berikut telah menjadi dasar dan prinsip setiap kebijakan politik dan langkah operasionalnya.

Al-Syumuliyah (Lengkap dan Integral)

Sesuai dengan karakteristik da'wah Islam yang syamil, maka setiap kebijakan Partai akan selalu dirumuskan dengan mempertimbangkan berbagai aspek, meman dangnya dari berbagai perspektif, dan mensinkronkan antara satu aspek dengan aspek lainnya.

\section{Al-Ishlah (Reformatif)}

Setiap kebijakan, program, dan langkah yang ditempuh Partai selalu berorientasi pada perbaikan (ishlah), baik yang berkaitan dengan perbaikan individu, masyarakat, ataupun yang berkaitan dengan perbaikan pemerintahan dan negara. dalam rangka meninggikan kalimat Allah, memenangkan syari'at-Nya, dan menegakkan daulah-Nya.

Al-Syar'iyah (Konstitusional)

Syari'ah yang berisi hukum-hukum Allah SWT telah menetapkan hubungan pokok antara manusia terhadap Allah (hablun min Allah) dan hubungan terhadap diri sendiri dan orang lain (hablun min al-nas). Menjunjung tinggi syari'ah, ketundukan, dan komitmen kepadanya dalam seluruh aspek kehidupan merupakan kewajiban setiap muslim sebagai konsekuensi keimanannya. Komitmen itu wujud dalam bentuk keteguhan (al-istimsak) kepada al-haq, bulat hati dan percaya penuh kepada Islam sebagai ajaran yang lurus dan konprehensif yang harus ditegakkan dalam seluruh aspek kehidupan dengan tetap menjaga fleksibiltas sebagai ciri dari syari'at Islam serta mempertimbangkan aspek legalitas formal yang tidak bertentangan dengan syari'ah. Demi terwujudnya makna kemerdekaan sejati semua peraturan yang ada dalam Al-Quran dan As-Sunnah menjadi dasar konstitusi bagi seluruh kebijakan, program dan perilaku politik. Sebab kemandirian refrensi syari'at pada kekuasaan negara dan penegak hukum memberikan jaminan penting dalam merealisir amanah dan melawan kedhaliman.

\section{Al-Wasathiyah (Moderat)}

Masyarakat muslim disebut sebagai masyarakat "tengah" (ummatan wasatha). Simbol moralitas msyarakat Islam tersebut melahirkan prilaku, sikap, dan watak moderat (wasathiyah) dalam sikap dan interaksi muslim dengan berbagai persoalan. Al-wasathiyah yang 
telah menjadi ciri Islam baik dalam aspek-aspek nazhariyah (teoritis) dan amaliyah (operasional) atau aspek tarbiyah (pendidikan) dan tasyri iyah (perundang-undangan) harus merefleksi pada aspek ideologi ataupun tashawwur (persepsi), ibadah yang bersifat ritual, akhlak, adab (tatakrama), tasyri' dan dalam semua kebijakan, program, dan perilaku politik Partai Keadilan Sejahtera. Dalam tataran praktis sikap kemoderatan ini dinyatakan pula dalam penolakannya terhadap segala bentuk ekstremitas dan eksageritas kezhaliman dan kebathilan.

\section{Al-Istiqamah (Komit dan Konsisten)}

Oleh sebab berpegang teguh kepada ajaran dan aturan Islam (43: 43) merupakan ciri seorang muslim maka komitmen dan konsistensi kepada gerakan Islam harus menjadi inspirasi setiap geraknya. Konsekuensinya seluruh kebijakan, program, dan langkah-langkah operasional Partai harus istiqamah (taat asas) pada "hukum transenden" yang ditemukan dalam keseluruhan tata alamiah dan dalam keseluruhan proses sejarah (ayat-ayat kawniyat-Nya), dalam Kitabkitab-Nya (ayat-ayat qawliyat-Nya) dan dalam sunnah Rasulullah SAW, dalam konsensus ummat, serta dalam elaborasi tertulis oleh para mujtahid yang program sebelumnya. berkompeten mengeluarkan hukum-hukum terhadap masalah yang benar-benar tidak ditemukan secara tekstual dalam Risalah orisinal (al-Qur`an dan al-Sunnah). Konsistensi menuntut kontinyuitas (al-istimrar) dalam gerakan dalam arti adanya kesinambungan antara kebijakan dan Kekonsistenan para anggota PKS memiliki militansi kader yang kuat dan adanya seorang murabi yang mengajarkan dengan keikhlasan hati tanpa pamrih

Al-Numuw wa al-Tathawwur (Tumbuh dan Berkembang)

Konsistensi yang menjadi watak Partai Keadilan Sejahtera tidak boleh melahirkan stagnan bagi gerakan dan kehilangan kreatifitasnya yang orisinal. Maka prinsip al-numuw wa al-tathawwur (pertum-buhan yang bersifat vertikal dan perkembangan yang bersifat horizontal) harus menjadi prinsip gerakannya dengan tetap mengacu kepada kaidah yang bersumber dari nilai-nilai Islam. Oleh karena itu Partai dalam kebijakan, program dan langkah-langkah operasionalnya harus tetap konsern kepada pengembangan potensi SDM hingga mampu melakukan eksalarasi mobilitas vertikal dan perluasan mobilitas horizontal. 


\section{Al-Tadarruj wa Al-Tawazun (Bertahap, Seimbang dan Proporsional)}

Pertumbuhan dan perkembangan gerakan da'wah Partai mesti dilalui secara bertahap dan proporsional, sesuai dengan sunnatullah yang berlaku di jagat raya ini. Seluruh sistem Islam berdiri di atas landasan kebertahapan dan keseimbangan. Kebertahapan dan keseimbangan merupakan tata alamiah yang tidak akan mengalami perubahan. Manusia secara fithrah tercipta dalam kebertahapan dan keseimbangan yang nyata. Maka semua tindakan manusia, lebih-lebih tindakan politik, yang berupaya memisahkan diri dari kebertahapan, keserasian dan keseimbangan akan berakibat pada kehancuran yang karenanya dapat dikategorikaan sebagai kejahatan bagi kemanusiaan dan lingkungan sejagat. Oleh sebab itu kebertahapan dan keseimbangan (tadarruj dan tawazun) harus melekat dalam seluruh kiprah Partai, baik dalam kiprah individu fungsionaris dan pendukung nya ataupun kiprah kolektifnya.

Al-Awlawiyat wa Al-Mashlahah (Skala Prioritas dan Prioritas Kemanfaatan)

Efektivitas sebuah gerakan salah satunya ditentukan oleh kemampuan gerakan tersebut dalam menentukan prioritas langkah dan kebijakannya. Sebab segala sesuatu mempunyai saat dan gilirannya. Amal perbuatan memiliki keutamaan yang bertingkat-tingkat pula (9: 19-20), dari yang bersifat strategis, politis, sampai ke yang bersifat taktis. Prinsip al-awlawiyat dalam gerakan pada hakikatnya refleksi dari budaya berpikir strategis. Oleh sebab itu kebijakan, program, dan langkah-langkah operasionalnya didasarkan kepada visi dan misi partai. Prinsip al-awlawiyat dapat melahirkan efisiensi dan efektifitas gerakan. Di samping itu, Partai Keadilan Sejahtera yakin bahwa sebaik-baik muslim adalah yang paling bermanfaat bagi kepentingan manusia. Maka pada hakikatnya mashlahah ummah menjadi dasar dan prisip dalam kebijakan, program, dan langkah-langkah operasionalnya. Untuk itu ia akan tetap konsern terhadap semua persoalan yang dihadapi ummat. Kepentingan ummat selalu menjadi pertimbangan dan perioritas. Maka baik dalam kebijakan ataupun dalam sikap dan operasional harus selalu memiliki keberpihakan yang jelas terhadap kepentingan ummat. Kepentingan ummat harus diletakkan di atas kepentingan kelompok dan individu. 


\section{Al Hulul (Solusi)}

Partai Keadilan Sejahtera sesuai dengan namanya, ia memperjuangkan aspek-aspek yang yang tidak hanya berhenti pada janji, teori maupun kegiatan yang tidak dirasakan manfaatnya oleh ummat. Keadilan dan kesejahteraan haruslah diperjuangkan dengan ihsan dan itqon (profesional), itulah yang mengharuskan partai dan aktivisnya mengarahkan aktivitas dan program partai untuk menjadi solusi dan merealisirnya di setiap aktivitas yang mereka tempuh. Al-Mustaqbaliyah (Orientasi masa depan)

Pada kenyataannya tiga dimensi waktu (masa lalu, masa kini, dan masa mendatang) merupakan realitas yang saling berhubungan. Disadari, sasaran da'wah yang akan diwujudkan merupakan sasaran besar, yaitu tegaknya agama Allah di bumi yang menyebarluaskan keadilan dan kesejahteraan bagi seluruh ummat manusia yang layak memikul amanah khilafah (1998), yang bisa jadi yang akan menikmati keberhasilannya adalah generasi mendatang. Maka seyogyanya setiap kebijakan yang diambil dan program-program yang dicanangkan mengaitkan ketiga dimensi waktu tersebut. Masa lalu sebagai pelajaran, masa kini sebagai realitas, dan masa depan sebagai harapan. Keadaan yang kita geluti sekarang merupakan refleksi masa lalu kita dan sekaligus akan menentukan masa depan kita. Maka sangat bijak kalau kebijakan, program, dan langkah-langkah yang ditempuh tidak menge nyamping kan ketiga dimensi waktu tersebut dan selalu berorientasi pada masa depan, tidak hanya memikirkan nasib kita sekarang ini.

Al-'Alamiyah (Bagian dari da'wah sedunia)

Pada hakikatnya gerakan da'wah Islamiyah, baik tujuan ataupun sasaran yang akan dicapai, bersifat 'alamiyah (mendunia) sejalan dengan universalitas Islam. Hal itu telah menjadi sunnatudda'wah. Ia merupakan aktivitas yang tidak kenal batas etnisitas, negara, atau daerah tertentu. Kenyataan itu menegaskan bahwa eksistensi da'wah kita merupakan bagian dari da'wah 'alamiyah. Oleh sebab itu prinsip kebijakan da'wah kita tidak lepas dari kebijakan dan gerakan da'wah sedunia. Adalah suatu kemestian setiap kebijakan yang diambil, program yang dicanangkan, dan langkah-langkah yang ditempuh selaras dengan kebijakan da'wah yang bersifat alami dan tunduk pada 
sunnatudda'wah tersebut dengan tidak melikuidasi persoalan khas yang dihadapi di masing-masing wilayah.

\section{Sikap PKS di Panggung Pilpres 2009}

Peserta Pemilu Legislatif 2009 yang berjumlah 44 partai politik dari 38 partai politik nasional, hanya 9 partai yang memenuhi ambang batas perolehan suara 2,5 persen. Sementara 29 partai lainnya harus tersingkir. Dengan konsekuensinya partai yang tidak memenuhi syarat electoral treshold tidak mendapatkan kursi pada dewan perwakilan rakyat baik pusat maupun di daerah, PKS termasuk 9 partai yang lolos untuk mewakili rakyat pemilih untuk memduduki kursi panas parlemen di pusat dan daerah.

Berikut perolehan 9 partai politik tersebut secara lengkap:

1. Partai Demokrat 21.703.137 suara $=20,85 \%$ (150 kursi)

2. Partai Golkar $\quad 15.037 .757$ suara $=14,45 \%$ (107 kursi)

3. PDI-P 14.600 .091 suara $=14,03 \%$ ( 95 kursi)

4. PKS 8.206.955 suara $=7,88 \%$ ( 57 kursi)

5. PAN 6.254 .580 suara $=6,01 \%$ ( 43 kursi)

6. PPP 5.533.214 suara $=5,32 \%$ ( $37 \mathrm{kursi}$ )

7. $\mathrm{PKB} \quad 5.146 .122$ suara $=4,94 \%$ ( $27 \mathrm{kursi}$ )

8. Gerindra 4.646.406 suara $=4,46 \%$ ( 26 kursi)

9. Hanura 3.922 .870 suara $=3,77 \%$ ( 18 kursi)

Sumber: KPU Sabtu, 09/05/2009 22:29 WIB

Dalam pemilihan Presiden 8 Juli 2009, PKS berkoalisi dengan partai demokrat, PAN, PPP, PKB dan partai-partai yang merapat kepada partai yang dimungkinkan akan menang pada pemilihan presiden tersebut. Dan Partai Demokrat mengusung calonnya sendiri yaitu mencalonkan Susilo Bambang Yudhoyono sebagai capres, sedangkan untuk cawapres belum ditentukan akan mengandeng siapa.

Menurut tim sukses SBY ada 19 nama cawapres yang akan dipilih oleh tim 9 dari partai Demokrat untuk diusulkan kepada capres SBY agar dipilih salah satunya, namun pada akhirnya capres SBY tidak memilih dari salah satu partai yang berkoalisi dengan partai Demokrat. 
Dan yang dipilih oleh capres SBY adalah dari kalangan akademisi atau non-partai yaitu Boediono sebagai calon wakil presiden pilihan SBY. Sehingga partai yang berkoalisi dianggap tidak dilibatkan dalam menentukan cawapres.

PKS adalah partai yang paling keras menentang Boediono sebagai cawapres pilihan SBY, sebut saja wakil sekjen PKS H. Fahri Hamzah, SE dan Dr. Zulkieflimansyah, M.Sc yang mengatakan akan mencabut dukungan kepada capres SBY dan koalisi dengan partai Demokrat apabila tetap akan menggandeng Boediono sebagai cawapres. Namun ancaman dari PKS tidak terbukti sampai dengan deklarasi di laksanakan di Sabuga Bandung karena PKS tetap mendukung Boediono sebagai pendamping SBY.

Ketidak konsistenan PKS menjadi sebuah pertanyaan besar yang patut dilontarkan kepada partai dakwah tersebut, apa yang dicari PKS sehingga tetap mendukung SBY padahal mereka sudah mengancam akan mencabut dukungan apabila capres SBY tetap akan menggandeng Boediono sebagai cawapresnya. Apakah karena ada "iming-iming" penambahan jatah menteri di kabinet nanti? Atau karena apa? Perubahan sikap PKS yang sangat cepat itu terjadi setelah capres SBY sengaja mengundang pengurus teras PKS di Hotel Horison Bandung sebelum beberapa jam acara deklarasi pasangan SBY-Boediono di Sabuga.

\section{Penutup}

Jika dianalisis, ada beberapa penyataan penting. Pertama; berbagai kemungkinan dalam politik memang bisa saja terjadi walaupun dalam hitungan hari, jam, menit bahkan detik, akan tetapi perlu diingat bahwa partai yang berasaskan Islam mestinya harus istiqamah dalam kata dan perbuatan untuk berbuat dan bertindak agar para pendukung dan simpatisan partai tersebut tetap solid dan dapat dipercaya baik kepada PKS atau partai yang berasaskan Islam atau juga partai yang berbasis umat Islam.

Kedua; kenapa partai-partai yang berasaskan Islam tidak berkoalisi dengan sesama partai Islam atau partai platformnya sama untuk mengusung kader mereka untuk dijadikan capres dan cawapres? Kita bisa melihat, bahwa partai yang berasaskan Islam sangat 
memenuhi syarat 20 persen suara nasional dalam undang-undang pilpres yang di bentuk DPR untuk mengusung capres dalam partainya sendiri.

Ketiga, Pada saat bersamaan, iklim reformasi yang memberi angin segar bagi sejumlah partai Islam atau partai yang mayoritas berbasis umat Islam sangat memungkinkan untuk bersatu dalam membentuk sebuah pemerintahan yang bersih, jujur dan adil untuk kesejahteraan rakyat.

Keempat, Persyaratan untuk maju mengusung capres dari partai Islam sudah terpenuhi, tetapi kenapa hal itu tidak dilakukan? Disinilah lemahnya partai Islam atau partai yang mayoritas berbasis umat Islam untuk bersatu dalam ikatan emosional keagamaan belum dapat terealisasi. Pertanyaan berikutnya, Kapan partai Islam atau partai yang berbasis umat Islam akan bersatu atau bisa bersatu? Jawabannya Wallahu alam bi ashawab!

\section{DAFTAR PUSTAKA}

Djony Edward, Efek Bola Salju Partai Keadilan Sejahtera, PT. Syamil Cipta Media, Bandung, 2006

Ibnu Khaldun, Mukaddimah, Pustaka Pirdaus, Jakarta, 2002

Kartini Kartono, Patologi Sosial, jilid I, PT. RajaGrafindo Persada, Jakarta, 2005

www.kpu.go.id

Untung Wahono, dkk., Profil Singkat, Partai Keadilan Sejahtera, Sekjen Bidang Arsip dan Sejarah DPP PKS, Jakarta, 2007

Heru Nugroho, Dinamika Demokrasi di Indonesia, Dalam Harian Umum Pikiran Rakyat, tanggal 14 Agustus 2008.

Harian Umum Sore, Sinar Harapan, tanggal, 12 Juli 2009

Tim MPP PKS, Platform Kebijakan Pembangunan Partai Keadilan Sejahtera, MPP PKS Jakarta 2007

, Sekilas Partai Keadilan. Sekretariat DPP Partai Keadilan, Jl. Mampang Prapatan Raya Jakarta Selatan, 1998. 